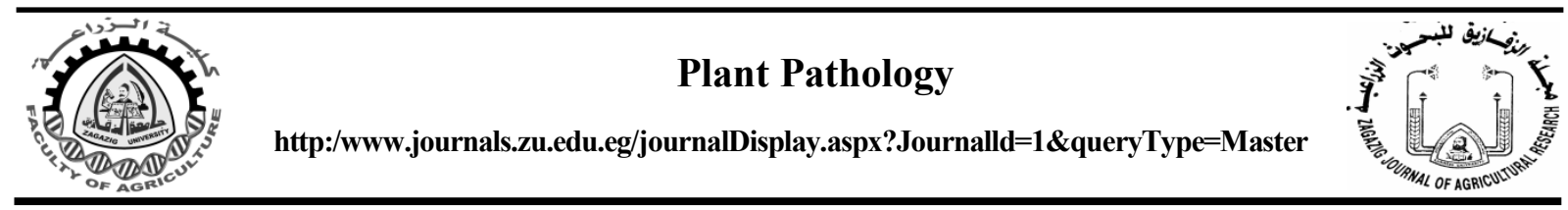

\title{
ROLE OF ORGANIC AMENDMENTS IN CONTROLLING BACTERIAL WILT OF SOME SOLANACEOUS PLANTS UNDER ARTIFICAL INOCULATION CONDITIONS
}

\author{
Naser M. El-Sarkassy ${ }^{{ }^{*}}$, M.A.M.S. Ali ${ }^{2}$ and Rahma Abd-Elrahim ${ }^{2}$ \\ 1. Agric. Bot. Dept., Fac. Agric., Zagazig Univ., Egypt \\ 2. Plant Pathol. Dept., Fac. Agric., Zagazig Univ., Egypt
}

Received: 1/11/2017; Accepted: 3/12/2017

\begin{abstract}
Bacterial wilt disease of Solanaceae plants caused by Ralstonia solanacearum is an economic quarantine disease worldwide. The disease is difficult to control when established himself in cultivated area. This study was concerned to evaluate seven different organic amendments to control the disease on potato and tomato plants, under artificial inoculation conditions. Obtained results revealed that all of animal manure, poultry and dove compost were increased population of fungi, bacteria and actinomycetes in root rhizosphere, but did not affect the population of Ralstonia solanacearum cell concentration. However, animal manure, mixture1 (animal manure + vegetarian) and mixture 2 (animal manure + poultry) compost decreased population of pathogen cell concentration in root rhizosphere. The least percentage of disease incidence and severity were obtained when animal manure, mixture 1 and mixture 2 composts were used at 10-20\% concentrations in soil infested with bacterial wilt pathogen, followed by vegetarian (sugar cane) and vegetarian (etr). While, poultry and dove composts were lower effective in decreasing percentage of disease incidence and severity under artificial inoculation conditions. The animal manure, mixture 1, mixture 2, vegetarian (sugar cane), vegetarian (etr) composts increased tubers number and weight, number of tomato shoots and dry weight of leaves, stems and roots of potato and tomato plants as well as chlorophyll a and b but decreased carotenoids in plant leaves. While, Poultry and dove composts were less effective on these parameters. Both of polyphenol oxidase and peroxidase activity were increased at different degrees in plants treated with different composts.
\end{abstract}

Key words: Ralstonia solanacearum, compost, solanaceae plants, organic amendments, bacterial wilt.

\section{INTRODUCTION}

Tomato (Solanum lycopersicum L.) and Potato (Solanum tuberosum, L.) are the most economically important vegetable crops in Egypt and the most widely grown vegetables in the world. The disturbance of their production through plant disease affects severely their local and export impact, because there are considered a very important consumption crops with high nutritional value and a potential export crops for the Egyptian farmers where about $20 \%$ of total area devoted for vegetable production is cultivated with potato. Bacterial wilt is a serious

\footnotetext{
* Corresponding author: Tel. : +201001995068
}

E-mail address: Naser_elsarkassy@yahoo.com economic disease causes problem in several countries where potatoes are cultivated over large areas for consumption and/or economical exportation crop including Egypt. Ralstonia solanacearum is the most devastating bacterial pathogen which infect more than 50 botanical families. The bacterium is found worldwide, mainly in tropical and subtropical areas, but also in warm temperate countries and even in some cool temperate regions (Hayward et al., 1998 ; Peeters et al., 2013). R. solanacearum race 3 biovar $2(\mathrm{R} 3 \mathrm{Bv} 2)$ is an economically important soil borne plant pathogen that causes bacterial wilt disease by infecting host plant roots and 
colonizing the xylem vessels (Colburn-Clifford and Allen 2010).

This pathogen became endemic in Egyptian soil for its ability to inhabit as saprophyte on non-host plant and parasite on other susceptible host plants (Gado, 2013). Because of $R$. solanacearum is a soil borne pathogen and host resistance limited, bacterial wilt is very difficult to control in production fields on some crops such as potato and tomato (Hayward, 1991; Saddler, 2005). Moreover, R. solanacearum is widely distributed and has an unusually broad host range (Denny, 2006). Thus, no single strategy could be considered as $100 \%$ effective in controlling the disease. Therefore, bacterial wilt control are possible by using a combination of diverse control methods as a part of integrated management strategy.

Different management strategies of bacterial wilt disease have been studied in worldwide with special focus on host plant resistance, cultural practices, and soil amendments (Saddler, 2005). Soil amendments that enhance host plant resistance with inorganic and/or organic mixtures reduce wilt incidence in some locations. Soil with high organic matter content like those amended with cattle manure, household compost and crop residues are reported to release allelochemicals that suppress bacterial wilt populations (Datnoff et al. 2001; Bailey and Lazarovits, 2003 ; Schönfeld et al., 2003).

The widespread availability of organic fertilizer and its use in sustainable agriculture as environmentally safe bio-fertilizers and soil conditions is increasing all over the world. Yadessa et al. (2010) studied the effects of amending topsoil with three different levels (1, 5 and $10 \%$ ) of cocopeat, farmyard manure (FYM) and green compost, and two levels of bacterial inoculations on infected tomato by $R$. solanacearum compared to non-inoculated treatments. Higher disease severity was recorded in soil amended with $10 \%$ green compost compared to the control one revealing higher root and above-ground dry weight. Moreover, farm yard manure (FYM) added to topsoil at 5 and $10 \%$ gave significantly higher above-ground fresh weight. Three composts of pig manure, sewage sludge and medicinal herb residues promoted tomato growth, induced changes in physical and chemical properties, enzyme activities and the number of microorganisms of the substrate, which was speculated to be the mechanism for their suppressive effects on bacterial wilt of tomato caused by $R$. solanacearum (JianHua et al., 2012). In case of potato results of that pathogen revealed a remarkable decrease in plant growth related parameters, productivity and an increase in disease incidence (Youssef and Tartoura, 2013).

The role of oxidative enzymes and their metabolic products in defense mechanisms of cucumber plants has been extensively studied as marker for resistance (Hammerschmidt et al., 1982). Host-pathogen interaction leading to growth inhibition and distortion of development often lead to an increase in the activity of certain enzymes, particularly polyphenol oxidases and decrease or increase activity of plant growth regulators (Ride and Pearce, 1979). Plants possess a wide array of active defense responses that contribute to resistance against a variety of pathogens. They respond to bacterial pathogen attack by activating various defense responses including changes in cell metabolism, primarily in the enzyme activities that consist of phenylalanine ammonia lyase (PAL), peroxidase (POX), polyphenol oxidase (PPO), lipoxygenase, superoxide dismutase, and $\beta$-1,3-glucanase (Shivakumar et al., 2003; Babitha et al., 2004 on pearl millet and Girish and Umesha 2005 on tomato). Also, these enzymes are associated with the accumulation of several factors like defense related enzymes and inhibitors that serve to prevent pathogen infection. In this context, novel eco-friendly and safe strategies have been explored for the management of wilt diseases. Thus, induced systemic resistance (ISR) is one of the most important methods and is gaining worldwide importance and acceptance (VanWees et al., 2008).

Therefore, soil amendments with organic materials could be an indirect way of stimulating bio-control in the soil. The objectives of the current work are for studing the ability of different types of organic amendments at different rates to counteract or mitigate the adverse effects of biotic stress on Solanaceous plants grown in infested soil with Ralstonia solanacearum under the artificial inoculation conditions, Also, to evaluate the effect of organic amendments on the disease incidence 
and severity with particular reference to physiochemical and growth characters of potato and tomato.

\section{MATERIALS AND METHODS}

\section{Organic Amendments}

Seven types of organic amendments i.e. animal manure, mixture 1 (animal manure + vegetarian), mixture 2 (animal manure + poultry), vegetarian (sugar cane), vegetarian (etr.), poultry, and dove as soil amendment. Each amendment was added to the previously infested and non-infested soils with pathogen. Non-amended soil was used as the control treatment. Organic amendments were applied at two rates 10 and $20 \%(\mathrm{~W} / \mathrm{W})$, and stayed for 14 days at temperature of $18-20^{\circ} \mathrm{C}$ before sowing.

Animal manure, mixture1, vegetarian (etr.) and vegetarian (sugar cane) were kindly obtained from Service Center of Compost Production Unit, Moshtohor, Fac. Agric., Benha Univ. Egypt. Mixture2 was obtained from Shade Company, Zagazig, Sharkia Governorate. Egypt. The other two organic amendments (poultry and dove) were obtained from special farm at Wadi ElMolak, Abou-Hammad, Sharkia Governorate.

Chemical analyses of the seven investigated amendments are shown in Table (1). The mechanical analyses were done at Central Lab., Fac. Agric., Zagaszig Univ. Egypt.

This work was carried out in pot experiments, under greenhouse conditions of Plant Pathol. Dept., Fac. Agric., Zag. Univ., during the two successive seasons 2013/2014 in order to counteract or mitigate the adverse effects of biotic stress on Solanaceous plants grown in soil infested with Ralstonia solanacearum. Soil was used at the rate of one $1 \mathrm{Kg} /$ pot $(10 \mathrm{~cm}$ diameter) for tomato (TY3018 cultivar) and $5.0 \mathrm{Kg} /$ pot (30 $\mathrm{cm}$ in diameter) for potato (Pliny cultivar).

\section{Inoculation Preparation and Infestation Soils}

Pathogenic isolate of Ralstonia solanacearum (T4) was isolated from infected potato tuber and identified according to Abd-Elrahim et al. (2015). For infestation process, the bacteria were grown on triphenyl tetrazolium chloride
(TZC) agar medium at $28^{\circ} \mathrm{C}$ for $48 \mathrm{hr}$., and wildtype bacterial colonies (based on colony morphology) were harvested and suspended in casamino acids, peptone and glucose (CPG) liquid culture and grown for three days at room temperature (Kelman, 1954). Cultures were centrifuged at $10,000 \mathrm{rpm}$ for $10 \mathrm{~min}$ at $10^{\circ} \mathrm{C}$. Bacterial pellets were suspended in distilled water and adjusted to $10^{9} \mathrm{cfu} / \mathrm{ml}$ using the spectrophotometer.

The pathogen inoculum was added seven days before sowing to pots at a rate of 250 $\mathrm{ml} /$ pot for potato and $40 \mathrm{ml} /$ pot for tomato. The pots were sown with healthy four eye pieces of susceptible potato tubers (Pliny cultivar) and two with tomato healthy seedlings (TY3018 cultivar). Non-infested pots (soil only), and other pots containing infested soil were used as the control. Five pots were used as replicates for each treatment. These pots were arranged in completely randomized design.

All pots were watered regularly with tap water to near capacity. These pots did not receive any fertilizers in this study (Yadessa $e t$ al., 2010).

\section{Effect of Different Compost Types on}

\section{Population of fungi, bacteria and actinomycetes in infested soil with Ralstonia solanacearum}

Rhizospheric samples were collected from potato plants grown in pots filled with soil supplemented with compost and infested with R.solanacearum and compared with pot samples filled with soil infested with only $R$. solanacearum. Soil suspension was made for each sample through washing adhesive rhizosphere soil particles of potato roots in flasks containing $99 \mathrm{ml}$ of sterile tap water and shaking for $2 \mathrm{hr}$. at $1000 \mathrm{rpm}$. A series of dilutions, $10^{2}, 10^{3}, 10^{4}, 10^{5}, 10^{6}, 10^{7}, 10^{8}$, were prepared. Potato dextrose agar (PDA) according to Lelliott and Stead (1987), nutrient agar (NA) according to Shirling and Gottlieb (1966), and starch nitrate (SN) according to Jacobs and Gerstein (1960) media were used for isolation of fungi, bacteria and actinomycetes, respectively. The plates were incubated at $28^{\circ} \mathrm{C}$ for seven days and the developed colonies were counted and calculated as colony forming units (cfu)/ $\mathrm{g}$ soil. 
Table 1. Chemical analyses of the seven used amendment types

\begin{tabular}{lcccccccc}
\hline Chemical characters & \multicolumn{7}{c}{$\begin{array}{c}\text { Amend } \\
\text { Animal }\end{array}$} & \multicolumn{2}{c}{$\begin{array}{c}\text { Mixture } \\
\text { manure }\end{array}$} & $\mathbf{1}$ & $\mathbf{2}$ & $\begin{array}{c}\text { V. sugar } \\
\text { cane }\end{array}$ & V.etr & Poultry & Dove \\
& 25.1 & 19.04 & 20.7 & 16 & 7.41 & 9.95 & 1.44 \\
\hline Organic carbon (\%) & 49 & 32.82 & 35.5 & 21.6 & 12.77 & 17.15 & 2.48 \\
Organic matter (\%) & 14.5 & 9.66 & 18.3 & 17.2 & 12.56 & 13.6 & 18 \\
C/N (ratio) & 0.39 & 0.0063 & 1.03 & 0.22 & 0.00147 & 0.0023 & 0.0011 \\
Total phosphorus (\%) & 2.5 & 0.0145 & 2.11 & 0.31 & 0.0036 & 0.00412 & 0.00018 \\
Total potassium (\%) & & & & & & & \\
\hline
\end{tabular}

\section{Disease assessments}

The percentage of disease incidence and severity were determined after 7 days from inoculation in tomato seedlings and after four weeks for potato plants according to the following modified scale suggested by Winstead and Kelman (1952):

Disease incidence $(\%)=\frac{\text { No. of wilted plants }}{\text { Total No. of plants }} \times 100$

Disease seversity $(\%)=$

$\frac{\left.\sum \text { (No. of wilted plants in each category } \times \text { wilt grade }\right)}{\text { Total No. of plants } \times \text { highest grade }} \times 100$

Effect of organic amendment on plant growth parameters

At the end of the experiment, random samples, each of 3 plants were taken to determine plant growth characters in potato, as No. of tubers, weight of tubers per plant (g), dry weight per plant organs (g). In tomato No. of shoots, dry weight of leaves, stems and roots were determined.

\section{Determination of photosynthetic pigments}

Chlorophyll a., b. and carotenoids were extracted from fresh leaf sample of the previously mentioned experiments on potato and tomato plants, in vivo using pure acetone methods according to Fadeel's method (Fadeel, 1962). The pigments were filtered, the optical density of the filtrate was determined spectrophotometrically using the wave lengths 662, 644, 440.5 nm for Chl. a, Chl. b and Carotenoids, respectively. The pigments (as $\mathrm{mg} / \mathrm{g}$ fresh weight) were calculated according to Wettestein (1957).

\section{Determination of enzymes activity}

\section{Polyphenol oxidase activity}

Fresh samples of potato and tomato leaves were collected. Samples crushed well in $2 \mathrm{ml}$ sodium phosphate buffer 0.1 at $\mathrm{pH} 7.1$ and filtered through Whatman No.1 filter paper. The obtained suspension was centrifuged at 6000 $\mathrm{rpm}$ at $4^{\circ} \mathrm{C}$ for $20 \mathrm{~min}$, resulted supernatant stored at $-8^{\circ} \mathrm{C}$ until use. One tenth extracted sample was added to $0.5 \mathrm{ml}$ sodium phosphate buffer $0.1 \mathrm{ml}$ at $\mathrm{pH} 7$ and $0.5 \mathrm{ml}$ catechol 0.001 $\mathrm{N}$. The mixture was completed to $3 \mathrm{ml}$ using distilled water and color density was read in spectrophotometer 601 at $495 \mathrm{~nm}$ wave length (Lisker et al., 1983). Polyphenol oxidase activity was calculated as $\mathrm{mg} / \mathrm{g}$ fresh weight.

\section{Peroxidase activity}

Potato and tomato leaf samples were extracted as mentioned before in polyphenol oxidase activity. One tenth extracted enzyme sample was added to $0.5 \mathrm{ml}$ sodium phosphate buffer $0.1 \mu$ at $\mathrm{pH} 7.1,0.1 \mathrm{ml} \mathrm{H}_{2} \mathrm{O}_{2} 1 \%$ and $0.3 \mathrm{ml}$ pyrogallol $0.05 \mu$. The mixture was completed to $3 \mathrm{ml}$ using distilled water and color density was read in absorbance spectrophotometer 601 at $425 \mathrm{~nm}$ wave length (Kochba et al., 1977). Peroxidase activity was calculated as $\mathrm{mg} / \mathrm{g}$ fresh weight.

\section{Statistical Analysis}

The data of all experiments were analyzed statistically using analysis of variance according to Gomez and Gomez (1984). Means were compared using the least significant differences (LSD). 


\section{RESULTS AND DISCUSSIONS}

\section{Effect of Different Compost Types on Population of Fungi, Bacteria and Actinomycetes in Potato Plants Rhizosphere Soil Infested with Ralstonia solanacearum}

It is clear from the results in Table 2 that, the population density of microorganisms in the potato rhizosphere on three selective media showed three kinds of microorganisms, fungi, bacteria and actinomycetes in soil treated with seven different types of compost. The number of culturable fungi recovered from rhizosphere soil treated with composts in control treatment (noninfested soil) was in descending order in the soil amended with animal manure, poultry, dove, mixture1, mixture2, vegetarian (sugar cane) and vegetarian (etr) composts indicating $20.3,17.0,15.3,15.3,13.7,7.3$ and $7.3 \times 10^{3}$ dilutions, respectively. Number of culturable bacteria recovered from rhizosphere soil treated with animal, dove, Mixture1, poultry, Mixture 2, vegetarian (sugar cane), and vegetarian (etr) composts of the non-infested soil with $R$. solanacearum ranged from 47.3 , up to $21.3 \mathrm{x}$ $10^{8}$ dilution. The number of culturable fungi recovered from rhizosphere soil treated with compost and infested with $R$. solanacearum was in descending order in the soil treated with the same previously mentioned composts being from 17.7, up to $7.0 \times 10^{3}$ dilution, compared with infested control $\left(5.0 \times 10^{3}\right)$. While, the population of culturable bacteria recovered from rhizosphere soil amended with compost and infested with $R$. solanacearum was gradually increase in soil amended with animal, mixture1, mixture2, vegetarian (etr), vegetarian (sugar cane), poultry and dove composts being from 84.3 , up to $189.3 \times 10^{8}$ dilution, compared with infested control $\left(199.7 \times 10^{8}\right)$. On the other hand, actinomycetes did not recover from most examined compost except for soil manured with animal and dove resulting 7.3 and $4.7 \times 10^{6}$ dilution, respectively.

Results revealed a positive correlation between investigated composts and population of microorganisms in potato rhizosphere soil. Composts have been used as soil amendments for centuries mainly to enhance soil fertility maintenance or improve organic matter level as well as biological and physical properties of the amended soil (Millner et al., 2004). Microbial activity in soils has been suggested by many authors as a result of organic fertilizers amendment, where most of the carbon supplied by this amendment comprises partially decomposed materials, easily degradable to be used as energy and nutrient source for soil microorganisms, resulting in an increase in soil microbial respiration and enhanced physical and chemical properties on organic and conventual farms (Bulluck et al., 2002; Heinze et al., 2011).

Amemiya (2007) and Gina et al. (2008) found that, compost amendment resulted in the increase of soil microbial activity and development of diversified bacterial communities in the rhizosphere of plants. Moreover, other research workers revealed that compost contains a higher levels of relatively available nutrients elements, which are essentially required to plant growth especially nitrogen and micronutrient elements (El-Etr et al., 2004).

\section{Effect of Different Compost Types on Bacterial Wilt Disease of Potato and Tomato Plants In vivo}

Results illustrated in Table 3 of both potato and tomato indicate that, the highest percentage of disease incidence was recorded in soil infested with Ralstonia solanacearum and amended with 20 and $10 \%$ concentration of dove compost $(97.30 \%$ and $89.30 \%$, in potato as well as $93.0 \%$ and $90.0 \%$, in tomato, respectively) followed by 20 and $10 \%$ poultry compost $(82.80 \%$ and $75.30 \%$, in potato in addition $88.3 \%$ and $84.0 \%$, in tomato, respectively).

Lower disease incidence percentage was recorded in pots amended with infested soil at 20 and $10 \%$ concentration of animal manure, mixture1, mixture2, vegetarian (sugar cane) and vegetarian (etr) composts ranging from 22.0; up to 62.0 and $65.8 \%$ of potato and $18.7 ; 22.0$; up to $54.0 ; 63.0$, of tomato, respectively compared to the infested untreated control which recorded $100 \%$ and $100 \%$. On the other hand, the highest percentage of disease severity was recorded in amended infested soil with 20 and $10 \%$ concentration of dove compost $(91.70 \%$ and $85.00 \%$ of potato), $86.30 \%$ and $81.70 \%$ of tomato, respectively) followed by 20 and $10 \%$ poultry compost $(78.00 \%$ and $67.70 \%$ of potato, $77.8 \%$ and $73.7 \%$ of tomato, respectively). $R$. solanacearum was significantly suppressed in 
Table 2. Effect of different compost types on population of fungi, bacteria and actinomycetes in rhizosphere of infested soil with Ralstonia solanacearum

\begin{tabular}{|c|c|c|c|c|}
\hline \multirow[t]{2}{*}{ Compost type } & \multirow[t]{2}{*}{ Treatment } & \multicolumn{3}{|c|}{ Microorganism } \\
\hline & & Fungi $\left(10^{3}\right)$ & Bacteria $\left(10^{8}\right)$ & Actinomycetes $\left(10^{6}\right)$ \\
\hline \multirow[b]{2}{*}{ Animal } & Infected $*$ & 17.7 & 84.3 & 7.3 \\
\hline & Healthy $* *$ & 20.3 & 47.3 & 8.3 \\
\hline \multirow{2}{*}{ Mixture1 } & infected & 11.3 & 100.7 & - \\
\hline & Healthy & 15.3 & 41.7 & - \\
\hline \multirow[t]{2}{*}{ Mixture2 } & Infected & 10.3 & 140.7 & - \\
\hline & Healthy & 13.7 & 32.7 & \\
\hline \multirow{2}{*}{ Vegetarian (etr) } & Infected & 7.0 & 150.7 & - \\
\hline & Healthy & 7.3 & 21.3 & - \\
\hline \multirow{2}{*}{ Vegetarian (sugar cane) } & Infected & 7.0 & 160.0 & - \\
\hline & Healthy & 7.3 & 22.7 & - \\
\hline \multirow{2}{*}{ Poultry } & infected & 16.3 & 173.0 & - \\
\hline & Healthy & 17.0 & 35.3 & - \\
\hline \multirow[b]{2}{*}{ Dove } & Infected & 16.0 & 189.3 & 4.7 \\
\hline & Healthy & 15.3 & 43.0 & 5 \\
\hline \multirow{2}{*}{ Control } & Infected & 5.0 & 199.7 & 4 \\
\hline & Healthy & 6.0 & 13.3 & 5 \\
\hline
\end{tabular}

Table 3. Effect of different types of organic amendments on severity of bacterial wilt disease of potato and tomato plants under artificial inoculation conditions.

\begin{tabular}{|c|c|c|c|c|c|c|c|c|c|}
\hline \multirow{2}{*}{$\begin{array}{c}\text { Infested soil amended } \\
\text { with }\end{array}$} & \multirow{2}{*}{$\begin{array}{l}\text { Rate } \\
(\%)\end{array}$} & \multicolumn{4}{|c|}{ Potato plants } & \multicolumn{4}{|c|}{ Tomato plants } \\
\hline & & $\begin{array}{c}\text { Disease } \\
\text { incidence } \\
(\%)\end{array}$ & $\begin{array}{c}\text { Reduction } \\
(\%)\end{array}$ & $\begin{array}{l}\text { Disease } \\
\text { severity } \\
(\%)\end{array}$ & $\begin{array}{l}\text { Reduction } \\
\text { (\%) }\end{array}$ & $\begin{array}{c}\text { Disease } \\
\text { incidence } \\
(\%)\end{array}$ & $\begin{array}{c}\text { Reduction } \\
\text { (\%) }\end{array}$ & $\begin{array}{l}\text { Disease } \\
\text { severity } \\
(\%)\end{array}$ & $\begin{array}{c}\text { Reduction } \\
\text { (\%) }\end{array}$ \\
\hline \multirow{2}{*}{ Animal manure } & 10 & 27.0 & 73.0 & 21.0 & 77.7 & 22.0 & 77.0 & 21.0 & 79.0 \\
\hline & 20 & 22.0 & 78.0 & 19.3 & 79.5 & 18.7 & 81.3 & 15.0 & 85.0 \\
\hline \multirow{2}{*}{ Mixture1 } & 10 & 33.7 & 66.3 & 25.7 & 73.3 & 43.0 & 57.0 & 40.0 & 60.0 \\
\hline & 20 & 31.3 & 68.7 & 22.7 & 76.3 & 40.0 & 60.0 & 35.8 & 64.2 \\
\hline \multirow{2}{*}{ Mixture2 } & 10 & 47.3 & 52.7 & 42.0 & 57.0 & 32.3 & 67.7 & 30.0 & 70.0 \\
\hline & 20 & 42.3 & 57.7 & 41.0 & 58.0 & 30.3 & 69.7 & 25.3 & 74.7 \\
\hline \multirow{2}{*}{ Vegetarian (sugar cane) } & 10 & 58.3 & 41.7 & 53.8 & 45.2 & 50.7 & 49.3 & 45.7 & 54.3 \\
\hline & 20 & 53.3 & 42.3 & 48.8 & 50.2 & 47.0 & 53.0 & 41.30 & 58.7 \\
\hline \multirow{2}{*}{ Vegetarian (etr) } & 10 & 65.8 & 36.3 & 60.7 & 38.3 & 63.0 & 37.0 & 60.7 & 39.3 \\
\hline & 20 & 62.0 & 38.0 & 56.0 & 43.0 & 54.0 & 46.0 & 51.3 & 48.7 \\
\hline \multirow{2}{*}{ Poultry } & 10 & 75.3 & 24.7 & 67.7 & 27.3 & 84.0 & 15.3 & 73.7 & 32.3 \\
\hline & 20 & 82.8 & 17.3 & 78.0 & 22.3 & 88.3 & 11.7 & 77.8 & 22.0 \\
\hline \multirow{2}{*}{ Dove } & 10 & 89.3 & 10.7 & 85.0 & 18.3 & 90.0 & 10.0 & 81.7 & 15.0 \\
\hline & 20 & 97.3 & 3.7 & 91.7 & 15.7 & 93.0 & 7.0 & 86.3 & 8.3 \\
\hline \multirow{3}{*}{\multicolumn{2}{|c|}{$\begin{array}{l}\text { Infested soil untreated } \\
\text { Uninfested soil Healthy control } \\
\text { LSD at } 0.05\end{array}$}} & 100.0 & 00.0 & 99.0 & 00.0 & 100.0 & 0.0 & 100.0 & 1.0 \\
\hline & & 00.0 & 100.0 & 00.0 & 100.0 & 0.0 & 100.0 & 0.0 & 100.0 \\
\hline & & 3.289 & & 2.356 & & 3.13 & & 3.15 & \\
\hline
\end{tabular}

Mixture1 $=($ Animal manure + Vegetarian $)$ Mixture2 $=($ Animal manure + Poultry $)$ 
pots amended infested soil with 20 and $10 \%$ of animal manure, mixture1, mixture2, vegetarian (sugar cane) and vegetarian (etr) composts ranging from $19.30 ; 21.00$; up to 56.00 and $60.70 \%$ of potato while being $15 ; 21$; up to 51.3 and $60.7 \%$, of tomato, respectively compared to the infested untreated control $(99.00 \%$ and $100 \%)$.

It is worthy to mention that, animal manure, mixture1, mixtue 2, vegetarian (sugar cane) and vegetarian (etr) were more effective in reducing percentage of disease incidence and severity than poultry and dove compost. Compost amendment resulted in an increase of the soil microbial activity resulting in the development of diversified useful communities in the rhizosphere of plants. Disease suppression also occurred by manuring with sterilized compost of almost the same level as that of non-sterilized compost. Therefore, the disease suppression might be caused by indigenous soil microorganisms activated by the compost amendment rather than by those in the compost. Similar finding was observed by Sakthivigneswari and Vijayalakshmi (2016), who found that significant decrease in disease reduction percent of bacterial wilt in higher application of corncob, might be due to the formation of organic and inorganic acid during the decomposition of organic matter. Soe et al. (2016) demonstrated that applications of corncob compost, vermicompost and sugar cane bagasse were superior on the suppression of wilt incidence on tomato plant on a small-scale basis. However, corncob compost may increase disease intensity at higher rates.

\section{Effect of Different Types of Organic Amendments on Growth Parameters of Potato Plants in Soil Infested With Ralstonia solanacearum, Under Artificial Inoculation Conditions (In vivo).}

Results in Table 4 reveal that, infested soil amended with 20 and $10 \%$ of animal manure, mixture1, mixture 2, vegetarian (sugar cane), vegetarian (etr), exhibit the highest average number of potato tubers ranged from 11.3; 10.3; 9.0 ; up to 6.0 and 5.0 , respectively compared with infested soil in untreated control being 2.3. Similarly, weight of tubers $(\mathrm{g}) / \mathrm{plant}$ for two tested concentrations recording $159.0 ; 146.7$; till 92.7 and 87.3, respectively compared with infested soil in untreated control 35.70.
However, dry weight $(\mathrm{g})$ of leaves recording 3.15 ; 3.0 ; till 1.4 and 1.0 . On the other hand, stems recorded $2.8 ; 2.2$; till 0.8 and 0.7 and roots ranged from $1.9 ; 1.7$; up to 0.67 and 0.58 gram for 20 and $10 \%$, respectively, compared with infested soil in untreated control recorded 0.4, 0.37 and 0.11 , respectively. On the other hand, infested amended soil with 20 and $10 \%$ concentration of dove and poultry exhibit the least numbers of potato tubers being $3.0 ; 3.7 ; 4.0$ and 4.7 , respectively comparing with infested untreated control (2.3). However, weight of tubers/ plant of infested soil in untreated control, dry weight of leaves, stems and roots revealed the least values.

Obtained results are in harmony with those of Hernández and Bustamante (2001) who reported that the population of $R$. solanacearum was reduced in the absence of the host with addition of different types of compost in soil. They added that, better disease control was observed with the application of organic materials formed in fermented organic fertilizers compared to coffee pulp or sugar cane filter cake. The suppressive effects of composted farmyard manure might be attributed to high substrate availability with high $\mathrm{N}$ content [high Total Organic Carbon (TOC) content, high available $\mathrm{N}$ content, and a low $\mathrm{C} / \mathrm{N}$ ratio], and high microbial activity as bioagent in plant rhizosphere that inhibit the pathogen growth reach in organic matter and carbon as well as $\mathrm{C} / \mathrm{N}$ ratio and both phosphorous and potassium (Islam and Toyota, 2004). Other researchers also showed that the disease suppressive or enhancing might affected by the compost used depending on their chemical and biological composition (Litterick et al., 2004), as well as on the reduction of pathogen population involved in rhizosphere of treated plants (Termorshuizen et al., 2006). Also, high level of disease control resulted from compost application may be due to the role of compost in improving soil physical properties (Abd ElMouty et al., 2001). Moreover, compost contains higher levels of relatively available nutrients elements, which are essentially required to plant growth especially nitrogen and micronutrient elements (Awad, 2002; El-Etr et al., 2004). Moreover, El-Desuki et al., 2010 reported that, the vegetative growth of pea plants as well as fresh and dry weight of leaves and branches, green pods yield and pod quality were significantly increased by increasing the applied compost. 
Table 4. Effect of different types of organic amendments on growth parameters of potato plants in soil infested with Ralstonia solanacearum, under artificial inoculation conditions

\begin{tabular}{|c|c|c|c|c|c|c|c|c|c|c|c|}
\hline \multirow{4}{*}{$\begin{array}{l}\text { Infested soil amended } \\
\text { with }\end{array}$} & \multirow{4}{*}{$\begin{array}{l}\text { Rate } \\
(\%)\end{array}$} & \multicolumn{10}{|c|}{ Potato growth parameters } \\
\hline & & \multirow{2}{*}{\multicolumn{2}{|c|}{$\begin{array}{c}\text { Average } \\
\text { No. tubers }\end{array}$}} & \multirow{2}{*}{\multicolumn{2}{|c|}{$\begin{array}{c}\text { Weight of } \\
\text { tubers (g/plant) }\end{array}$}} & \multirow{2}{*}{\multicolumn{2}{|c|}{ Leaves }} & \multicolumn{4}{|c|}{ Dry weight (g) } \\
\hline & & & & & & & & \multicolumn{2}{|c|}{ Stems } & \multicolumn{2}{|c|}{ Roots } \\
\hline & & $\overline{\mathbf{A}}$ & Cont. & $\bar{A}$ & Cont. & $\bar{A}$ & Cont. & $\mathbf{A}$ & Cont. & $\overline{\mathbf{A}}$ & Cont. \\
\hline \multirow[t]{2}{*}{ Animal manure } & 10 & 10.30 & 11.70 & 146.70 & 154.30 & 3.00 & 3.30 & 2.20 & 3.20 & 1.70 & 2.2 \\
\hline & 20 & 11.30 & 13.70 & 159.00 & 171.30 & 3.15 & 3.50 & 2.80 & 3.60 & 1.90 & 2.5 \\
\hline \multirow[t]{2}{*}{ Mixture1 } & 10 & 8.30 & 10.70 & 122.30 & 148.80 & 2.40 & 2.80 & 1.73 & 2.20 & 1.20 & 1.6 \\
\hline & 20 & 9.00 & 11.30 & 134.30 & 155.00 & 2.50 & 3.03 & 2.10 & 2.70 & 1.40 & 1.9 \\
\hline \multirow[t]{2}{*}{ Mixture2 } & 10 & 7.70 & 9.00 & 102.70 & 128.00 & 2.00 & 2.50 & 1.30 & 1.80 & 0.90 & 1.00 \\
\hline & 20 & 8.00 & 9.70 & 110.70 & 132.70 & 2.10 & 2.70 & 1.60 & 2.10 & 1.01 & 1.30 \\
\hline \multirow[t]{2}{*}{ Vegetarian (sugar cane) } & 10 & 6.70 & 8.30 & 96.70 & 108.00 & 1.80 & 2.00 & 1.00 & 1.40 & 0.72 & 0.83 \\
\hline & 20 & 7.30 & 8.70 & 100.00 & 110.00 & 1.90 & 2.10 & 1.10 & 1.50 & 0.83 & 0.95 \\
\hline \multirow[t]{2}{*}{ Vegetarian (etr) } & 10 & 5.00 & 6.70 & 87.30 & 98.00 & 1.00 & 1.20 & 0.70 & 1.00 & 0.58 & 0.70 \\
\hline & 20 & 6.00 & 7.00 & 92.70 & 101.00 & 1.40 & 1.40 & 0.80 & 1.10 & 0.67 & 0.74 \\
\hline \multirow[t]{2}{*}{ Poultry } & 10 & 4.70 & 5.70 & 66.30 & 85.00 & 0.97 & 1.00 & 0.60 & 0.90 & 0.45 & 0.62 \\
\hline & 20 & 4.00 & 5.30 & 57.30 & 74.00 & 0.70 & 0.70 & 0.50 & 0.77 & 0.35 & 0.54 \\
\hline \multirow[t]{2}{*}{ Dove } & 10 & 3.70 & 5.00 & 47.30 & 68.00 & 0.61 & 0.60 & 0.46 & 0.60 & 0.28 & 0.44 \\
\hline & 20 & 3.00 & 4.70 & 40.00 & 64.70 & 0.43 & 0.50 & 0.40 & 0.50 & 0.14 & 0.31 \\
\hline \multicolumn{2}{|c|}{ Infested soil-Untreated control } & 2.30 & 7.30 & 35.70 & 99.70 & 0.40 & 1.20 & 0.37 & 0.80 & 0.11 & 1.40 \\
\hline \multicolumn{2}{|l|}{ LSD at 0.05} & 1.19 & 0.81 & 5.67 & 10.29 & 0.252 & 0.28 & 0.21 & 0.264 & 0.074 & 0.132 \\
\hline
\end{tabular}

Mixture1 = (Animal manure + Vegetarian) Mixture2 = (Animal manure + Poultry $)$

$\mathrm{A}=$ Infected plants with Ralstonia solanacearum Cont.= Healthy plants

Results in Table 5 reveal that infested soil amended with 20 and $10 \%$ concentration of animal manure, mixture 1, mixture 2, vegetarian (sugar cane), vegetarian (etr) composts, resulted higher average number of shoots ranging from $12.3 ; 11.0$; to 6.3 and 5.7 , respectively compared with infested untreated control.

These treatments indicate plant height ranging from 53.7; 51.7; up to 32.3 and $30.7 \mathrm{~cm}$, respectively compared with infected plants in untreated control $(18.0 \mathrm{~cm})$. Dry weight of leaves revealed values ranging from $3.0 ; 2.75$; up to 1.5 and 1.2 gram, respectively, while dry weight of stems ranging from $1.5 ; 1.2$; to 0.6 and 0.5 gram, respectively. On the other hand, dry weight of roots recorded values of $1.3 ; 1.1$; to 0.5 and 0.4 gram, respectively. The soil amended with 20 and $10 \%$ concentrations of dove and poultry compost indicated the lower average number of shoots which were 4.0, 4.3, 4.7 and 5.3, respectively, compared with infested untreated control (4.70).

Plant height valued as much as 20.0, 21.0; 24.30 and $28.3 \mathrm{~cm}$, respectively compared with infected plants in untreated control which recorded $18.0 \mathrm{~cm}$ and dry weight of leaves were $0.30 ; 0.47 ; 0.50$ and 0.65 gram, respectively, dry weight of stems were $0.20 ; 0.27 ; 0.30$ and 0.33 gram, respectively and dry weight of roots 0.13 ; $0.20 ; 0.25$ and 0.30 gram, respectively compared 
Table 5. Effect of different types of organic amendments on growth parameters of tomato plants in soil infested with Ralstonia solanacearum, under artificial inoculation conditions.

\begin{tabular}{|c|c|c|c|c|c|c|c|c|c|c|c|}
\hline \multirow{4}{*}{$\begin{array}{l}\text { Infested soil amended } \\
\text { with }\end{array}$} & \multirow{4}{*}{$\begin{array}{l}\text { Rate } \\
\text { (\%) }\end{array}$} & \multicolumn{10}{|c|}{ Growth parameters of tomato } \\
\hline & & \multirow{2}{*}{\multicolumn{2}{|c|}{ No. shoots }} & \multirow{2}{*}{\multicolumn{2}{|c|}{$\begin{array}{l}\text { Plant height } \\
\text { (cm) }\end{array}$}} & \multirow{2}{*}{\multicolumn{2}{|c|}{ Leaves }} & \multicolumn{4}{|c|}{ Dry weight (g) } \\
\hline & & & & & & & & \multicolumn{2}{|c|}{ Stems } & \multicolumn{2}{|c|}{ Roots } \\
\hline & & $\mathbf{A}$ & Cont. & $\bar{A}$ & Cont. & $\overline{\mathbf{A}}$ & Cont. & $\bar{A}$ & Cont. & $\mathbf{A}$ & Cont. \\
\hline \multirow{2}{*}{ Animal manure } & 10 & 11.00 & 12.00 & 51.70 & 55.30 & 2.75 & 3.00 & 1.20 & 1.50 & 1.10 & 1.40 \\
\hline & 20 & 12.30 & 13.30 & 53.70 & 61.70 & 3.00 & 3.30 & 1.50 & 1.70 & 1.30 & 1.60 \\
\hline \multirow{2}{*}{ Mixture1 } & 10 & 8.30 & 10.30 & 43.00 & 49.70 & 2.20 & 2.70 & 1.03 & 1.20 & 0.90 & 1.10 \\
\hline & 20 & 9.00 & 11.30 & 46.70 & 53.70 & 2.60 & 2.80 & 1.10 & 1.30 & 1.00 & 1.20 \\
\hline \multirow{2}{*}{ Mixture2 } & 10 & 7.30 & 9.70 & 40.30 & 43.30 & 2.00 & 2.50 & 0.90 & 1.00 & 0.70 & 0.90 \\
\hline & 20 & 8.00 & 10.00 & 42.70 & 48.00 & 2.15 & 2.60 & 1.00 & 1.10 & 0.80 & 1.00 \\
\hline \multirow{2}{*}{ Vegetarian (sugar cane) } & 10 & 6.70 & 8.00 & 33.30 & 37.70 & 1.60 & 1.60 & 0.70 & 0.80 & 0.53 & 0.76 \\
\hline & 20 & 7.00 & 9.00 & 35.30 & 40.70 & 1.70 & 2.00 & 0.80 & 0.90 & 0.60 & 0.80 \\
\hline \multirow{2}{*}{ Vegetarian (etr) } & 10 & 5.70 & 7.00 & 30.70 & 34.00 & 1.20 & 1.30 & 0.50 & 0.60 & 0.40 & 0.60 \\
\hline & 20 & 6.30 & 7.70 & 32.30 & 35.30 & 1.50 & 1.50 & 0.60 & 0.70 & 0.50 & 0.70 \\
\hline \multirow{2}{*}{ Poultry } & 10 & 5.30 & 6.00 & 28.30 & 30.00 & 0.90 & 1.20 & 0.43 & 0.50 & 0.37 & 0.70 \\
\hline & 20 & 4.70 & 4.70 & 24.30 & 27.00 & 0.65 & 0.97 & 0.33 & 0.43 & 0.30 & 0.50 \\
\hline \multirow{2}{*}{ Dove } & 10 & 4.30 & 6.30 & 21.00 & 25.30 & 0.50 & 0.77 & 0.30 & 0.40 & 0.25 & 0.60 \\
\hline & 20 & 4.00 & 5.00 & 20.00 & 16.30 & 0.47 & 0.60 & 0.27 & 0.30 & 0.20 & 0.50 \\
\hline \multicolumn{2}{|c|}{ Infested soil-Untreated control } & 4.70 & 7.30 & 18.00 & 19.30 & 0.30 & 1.03 & 0.20 & 0.90 & 0.13 & 0.80 \\
\hline \multicolumn{2}{|l|}{ LSD at 0.05} & 1.42 & 0.983 & 2.25 & 3.18 & 13.41 & 0.22 & 0.15 & 1.56 & 0.14 & 0.14 \\
\hline
\end{tabular}

Mixture1 = (Animal manure+ Vegetarian) Mixture2 = (Animal manure + Poultry)

$\mathrm{A}=$ Infected plants with Ralstonia solanacearum Cont.= Healthy plants

with dry weight of leaves, stem and roots in infested untreated control that recorded 0.30 , 0.20 and 0.13 gram, respectively.

Different compost compounds added to the infested soils, reduced plant disease incidence associated with increasing organic materials but, the mechanism(s) of disease reduction due to compost compounds have been for most part ignored. However, in order to optimize their efficacy, such information is vital. Many mechanisms have been proposed including stimulation of resident microbes with biocontrol activity, induction of systemic resistance in plants, generation of toxic chemicals, and in some amendments presence of toxic substances such as volatile fatty acids (VFAs). It is likely that more than one mechanism is involved but which ones play a dominant role is likely to be soil specific. Most, if not all, of the organic amendments enhance microbial activity but not all lead to the reduction of disease incidence.

The effects of organic amendments, suggests that both chemical and biological components of compost-amended soils can contribute to disease suppression (Zhang et al., 1998; Abbasi et al., 2002; Bulluck et al., 2002). However, a further characterization and understanding of the different mechanisms by which organic amendments reduce plant diseases incidence, improve the disease control effect and reduce variability (Hoitink and Boehm, 1999). It will also increase the spectrum of soils that can be treated. Frequent application of organic materials such as manure or compost eventually 
results in higher substrate availability for competitors, reducing the growth of pathogens in the rhizosphere and reducing their infection rate (Hoitink and Boehm, 1999). Also, it is well known that in soil infested with Ralstonia solanacearum and incorporation of cow dung manure suppressed growth of tomatoes bacterial wilt pathogen (Nishiyama et al., 1999). Also, household compost (Schönfeld et al., 2003), and pig slurry (Gorissen et al., 2004) have been found to reduce bacterial wilt incidence and severity caused by Ralstonia solanacearum. According to these facts Islam and Toyota (2004) reported that suppression of bacterial wilt of tomato (BWT) was observed in soils amended with poultry and farmyard manures. Suppression of bacterial wilt by pig slurry was also associated with a microbial community shift.

Different types of composts (garden wastes and cow manure) produced a higher number of tomato and cucumber leaves and shoots, high dry weight of leaves and shoots and a significant better growth of seedlings (Jahromi et al., 2012).

\section{Effect of Organic Amendments on Leaves Photosynthetic Pigments}

Results in Table 6 indicate that, the highest values of chlorophyll (a) were recorded in descending order being of 1.526 ; 1.363 ; ending with 0.695 . However, chlorophyll (b) being with 1.225 ; 1.197 ; ending with 0.629 and 0.510 for 20 and $10 \%$ concentration in wilted potato plants grown in soil infested with Ralstonia solanacearum and amended with compost of animal manure, mixture1, mixture2, vegetarian (sugar cane) and vegetarian (etr), respectively.

On the other hand, the lowest values of chlorophyll (a) recorded $0.382 ; 0.469 ; 0.497$ and 0.620 and for chlorophyll (b) recorded 0.235; $0.321 ; 0.378$ and 0.387 , at 20 and $10 \%$ of dove and poultry compost, respectively compared with infected untreated control $(0.218$ and $0.164)$, respectively.

The lowest values of carotenoids were ranging from $0.172 ; 0.259$; up to 0.644 and 0.694 at both 20 and $10 \%$ concentrations of animal, mixture1, mixture2, vegetarian (sugar cane) and vegetarian (etr) manure were investigated respectively. However, the highest values of carotenoids were $1.247 ; 0.919 ; 0.837$ and 0.741 , respectively at the 20 and $10 \%$ of dove and poultry compost compared with infested untreated control (1.261).

Increasing pigment contents in plants grown in soil infested with Ralstonia solanacearum and manured with compost could be explained as amending agricultural soil with organic matter supplies plant nutrients, increases natural suppressive of the soil against soil-borne pathogens and improves physicochemical and biological characteristics (Veeken et al., 2005 ; Janvier et al., 2007).

Results in Table 7 show that, the highest values of chlorophyll (a) recorded in descending order ranging from $1.373 ; 1.278$; up to 1.036 and 0.906. Chlorophyll (b) was ranging from 1.252 ; 1.183 ; to 0.853 and 0.738 when 20 and $10 \%$ in infected tomato plants grown in soil infested with Ralstonia solanacearum and amended with animal manure, mixture2, mixture1, vegetarian (sugar cane) and vegetarian (etr) composts were examined, respectively.

On the other hand, the lowest values of chlorophyll (a) indicated $0.295 ; 0.403 ; 0.417$ and 0.564 and for cholorophyll (b) indicated 0.278; $0.375 ; 0.389$ and 0.500 , respectively at $20-10 \%$ of dove and poultry compost compared with infected untreated control (0.214 and 0.128), respectively. However, the lowest values of carotenoids compared with control treatment were ranging from $0.176 ; 0.256$; up to 0.643 and 0.704 at 20 and $10 \%$ of animal manure, mixture1 manure, mixture2, vegetarian (sugar cane) and vegetarian (etr) composts, respectively. The highest values of carotenoids were 1.259, $0.877,0.859,0.719$, respectively for 20 and $10 \%$ of dove and poultry compared with infected untreated control (1.620).

This obtained results are in agreement with those obtained by Ancuța et al. (2013). They found that the effect of six types of compost in different percentage amounts, mixed with field soil and sand for tomato seedlings increased vegetative growth parameters (average plant height, number of leaves, chlorophyll index). These parameters were used to evaluate the efficiency of these substrates in seedlings production. Variants B3 with 50\% compost, S3 with $50 \%$ and S1 with $100 \%$ compost produced a higher number of leaves, a significantly better growth of seedlings and higher chlorophyll content than other variants. 
Table 6. Effect of different types of organic amendments on leaves photosynthetic pigments of potato plants grown in soil infested with Ralstonia solanacearum

\begin{tabular}{|c|c|c|c|c|c|c|c|c|c|}
\hline \multirow{3}{*}{$\begin{array}{l}\text { Infested soil amended } \\
\text { with }\end{array}$} & \multirow{3}{*}{$\begin{array}{c}\text { Rate } \\
(\%)\end{array}$} & \multicolumn{8}{|c|}{ Photosynthetic pigments of potato } \\
\hline & & \multicolumn{2}{|c|}{ Chlorophyll (a) } & \multicolumn{2}{|c|}{ Chlorophyll (b) } & \multicolumn{2}{|c|}{ Chlorophyll $(a+b)$} & \multicolumn{2}{|c|}{ Carotenoids } \\
\hline & & $\mathbf{A}$ & Cont. & $\mathbf{A}$ & Cont. & $\mathbf{A}$ & Cont. & $\mathbf{A}$ & Cont. \\
\hline \multirow[t]{2}{*}{ Animal manure } & 10 & 1.363 & 1.616 & 1.197 & 1.199 & 2.560 & 2.815 & 0.259 & 0.057 \\
\hline & 20 & 1.526 & 1.692 & 1.225 & 1.385 & 2.751 & 3.077 & 0.172 & 0.025 \\
\hline \multirow[t]{2}{*}{ Mixture1 } & 10 & 1.200 & 1.437 & 1.069 & 1.183 & 2.269 & 2.620 & 0.362 & 0.248 \\
\hline & 20 & 1.316 & 1.576 & 1.179 & 1.195 & 2.495 & 2.771 & 0.264 & 0.229 \\
\hline \multirow[t]{2}{*}{ Mixture2 } & 10 & 0.944 & 1.197 & 0.903 & 0.977 & 1.847 & 2.174 & 0.539 & 0.485 \\
\hline & 20 & 0.963 & 1.363 & 0.921 & 0.993 & 1.884 & 2.356 & 0.487 & 0.382 \\
\hline \multirow[t]{2}{*}{ Vegetarian (sugar cane) } & 10 & 0.833 & 0.942 & 0.797 & 0.949 & 1.640 & 1.891 & 0.642 & 0.557 \\
\hline & 20 & 0.885 & 1.059 & 0.844 & 0.963 & 1.729 & 2.022 & 0.624 & 0.430 \\
\hline \multirow[t]{2}{*}{ Vegetarian (etr) } & 10 & 0.695 & 0.818 & 0.510 & 0.946 & 1.205 & 1.764 & 0.694 & 0.660 \\
\hline & 20 & 0.810 & 0.875 & 0.629 & 0.954 & 1.439 & 1.829 & 0.644 & 0.528 \\
\hline \multirow[t]{2}{*}{ Poultry } & 10 & 0.620 & 0.694 & 0.387 & 0.47 & 1.007 & 1.164 & 0.741 & 0.637 \\
\hline & 20 & 0.497 & 0.563 & 0.378 & 0.451 & 0.875 & 1.014 & 0.837 & 0.836 \\
\hline \multirow[t]{2}{*}{ Dove } & 10 & 0.469 & 0.529 & 0.321 & 0.369 & 0.790 & 0.898 & 0.919 & 0.817 \\
\hline & 20 & 0.382 & 0.411 & 0.235 & 0.247 & 0.617 & 0.658 & 1.247 & 1.117 \\
\hline \multicolumn{2}{|c|}{ Infested soil- Untreated control } & 0.218 & 0.976 & 0.164 & 1.129 & 0.382 & 2.105 & 1.261 & 0.078 \\
\hline
\end{tabular}

Mixture1 $=($ Animal manure + Vegetarian $)$ Mixture2 $=($ Animal manure + Poultry $)$

$\mathrm{A}=$ Infected plants with Ralstonia solanacearum Cont.= Healthy plants

Table 7. Effect of different types of organic amendments on leaves photosynthetic pigments of tomato plants grown in soil infested with Ralstonia solanacearum

\begin{tabular}{|c|c|c|c|c|c|c|c|c|c|}
\hline \multirow{3}{*}{$\begin{array}{l}\text { Infested soil amended } \\
\text { with }\end{array}$} & \multirow{3}{*}{$\begin{array}{l}\text { Rate } \\
(\%)\end{array}$} & \multicolumn{8}{|c|}{ photosynthetic pigments of tomato } \\
\hline & & \multicolumn{2}{|c|}{ Chlorophyll (a) } & \multicolumn{2}{|c|}{ Chlorophyll (b) } & \multicolumn{2}{|c|}{ Chlorophyll $(\mathbf{a}+\mathbf{b})$} & \multicolumn{2}{|c|}{ Carotenoids } \\
\hline & & $\mathbf{A}$ & Cont. & $\mathbf{A}$ & Cont. & $\mathbf{A}$ & Cont. & $\mathbf{A}$ & Cont. \\
\hline \multirow{2}{*}{ Animal manure } & 10 & 1.278 & 1.554 & 1.183 & 1.280 & 2.461 & 2.834 & 0.256 & 0.055 \\
\hline & 20 & 1.373 & 1.579 & 1.252 & 1.364 & 2.625 & 2.943 & 0.176 & 0.040 \\
\hline \multirow{2}{*}{ Mixture1 } & 10 & 1.121 & 1.253 & 0.974 & 1.155 & 2.095 & 2.410 & 0.513 & 0.475 \\
\hline & 20 & 1.036 & 1.274 & 0.988 & 1.182 & 2.207 & 2.464 & 0.489 & 0.372 \\
\hline \multirow{2}{*}{ Mixture2 } & 10 & 1.244 & 1.309 & 1.065 & 1.201 & 2.309 & 2.475 & 0.377 & 0.175 \\
\hline & 20 & 1.267 & 1.312 & 1.168 & 1.218 & 2.435 & 2.530 & 0.315 & 0.136 \\
\hline \multirow{2}{*}{ Vegetarian (sugar cane) } & 10 & 1.055 & 1.137 & 0.890 & 1.059 & 1.945 & 2.196 & 0.643 & 0.524 \\
\hline & 20 & 1.219 & 1.228 & 0.934 & 1.115 & 2.003 & 2.368 & 0.606 & 0.477 \\
\hline \multirow{2}{*}{ Vegetarian (etr) } & 10 & 0.906 & 0.951 & 0.738 & 0.651 & 1.644 & 1.602 & 0.704 & 0.543 \\
\hline & 20 & 1.069 & 1.109 & 0.853 & 1.042 & 1.889 & 2.151 & 0.661 & 0.588 \\
\hline \multirow{2}{*}{ Poultry } & 10 & 0.564 & 0.664 & 0.500 & 0.476 & 1.064 & 1.140 & 0.719 & 0.655 \\
\hline & 20 & 0.417 & 0.584 & 0.389 & 0.471 & 0.806 & 1.055 & 0.859 & 0.625 \\
\hline \multirow{2}{*}{ Dove } & 10 & 0.403 & 0.440 & 0.375 & 0.407 & 0.778 & 0.847 & 0.877 & 0.813 \\
\hline & 20 & 0.295 & 0.362 & 0.278 & 0.382 & 0.573 & 0.744 & 1.259 & 1.064 \\
\hline Infested soil-Untreated control & & 0.214 & 1.192 & 0.128 & 1.226 & 0.342 & 2.418 & 1.620 & 0.081 \\
\hline
\end{tabular}

Mixture1 = (Animal manure+ Vegetarian) Mixture2 = (Animal manure + Poultry)

$\mathrm{A}=$ Infected plants with Ralstonia solanacearum Cont.= Healthy plants 
Effect of Organic Amendments on Polyphenol Oxidase and Peroxidase Activities in Leaves of Both Potato and Tomato Plants

Results in Table 8 show that, the highest activity values of polyphenol oxidase in infected potato leaves grown in soil infested with Ralstonia solanacearum were ranging from 0.485 ; 0.408 ; till 0.195 and 0.185 , and in tomato leaves were of $0.374 ; 0.286$; till 0.156 and 0.152 at 20 and $10 \%$ of animal manure, mixture 1 , mixture2, vegetarian (sugar cane) and vegetarian (etr) composts, respectively. However, the lowest values in potato leaves were of 0.132 ; 0.140 ; up to 0.143 and 0.149 in leaves of tomato plants at 20 and $10 \%$ of dove and poultry composts, respectively compared with infested untreated control that recorded 0.39 in potato and (0.130) in tomato.

It could also note that the highest activity values of peroxidase in infected potato leaves grown in soil infested with Ralstonia solanacearum were ranging from $0.559 ; 0.525$ till 0.309 and 0.291 and were ranging from $0.575 ; 0.565$ till 0.277 and 0.231 of tomato leaves at 20 and $10 \%$ in compost of animal, mixture2, mixture1, vegetarian (sugar cane) and vegetarian (etr) composts, respectively. While the lowest values of peroxidase in potato leaves were $0.227 ; 0.251 ; 0.273$ and 0.280 while, in tomato leaves were $0.143 ; 0.153 ; 0.162$ and 0.188 at the 10 and $20 \%$ dove and poultry composts compared with infested untreated control (0.442) in potato and (0.114) in tomato.

Similar results were obtained by JianHua et al. (2012). They used three types of composts which induced changes in physical and chemical properties, enzyme activity and the number of microorganisms of the substrate, which was speculated to be the mechanism for their suppressive effects on tomato wilt caused by $R$. solanacearum. On the other hand, Thipyapong et al. (2007) mentioned that, it is evident that the mechanism by which PPO contributes to disease limitation is still unclear. PPO may be participated in plant defense as a component of both the response and signaling process that ultimately limits disease progressing. In contrast, control seedlings were evaluated for resistance against $R$. solanacearum, the causal agent of bacterial wilt in potato. While $R$. solanacearum mainly attacks and moves through vascular system of potato, where accumulation of PPO is limited to phloem.

Kohl and Fokkema (1998); Caruso et al. (2001) and Nawar and Kuti (2003) stated that peroxidase considered as a play defense factor against invading pathogens of wheat grains. Other investigators reported that peroxidase is known to be involved in the oxidation of polymerization of hydroxy cinnamyl alcohols to yield lignin and cross-linking isodityrosine bridges in cell wall.

Also, peroxidase produces free radicals and hydrogen peroxide which are toxic to many microorganisms (Pena and Kuc, 1992).

Also, Tarrad et al. (1993) stated that increase in peroxidase activity enhances lignification in response to infection with pathogens which may restrict fungal penetration. Plant extracts, biocontrol agents and soil amendments with compost induced host resistance through increase activity of many enzymes such as peroxidase and polyphenol oxidase which considered as a defense factor against invading pathogens (Caruso et al., 2001; Nawar and Kuti, 2003).

\section{Conclusions}

These results clearly demonstrate that organic fertilizers could be used to counteract or mitigate fully or partially the harmful effects of pathogen (biotic) stress (Ralstonia solanacearum) and are capable of restoring yield potential. They may be useful in agronomic field situations. 
Table 8. Effects of different types of organic amendments on polyphenol oxidase and peroxidase enzymes activities in potato and tomato leaves grown in soil infested with Ralstonia solanacearum

\begin{tabular}{|c|c|c|c|c|c|c|c|c|c|}
\hline \multirow{3}{*}{$\begin{array}{l}\text { Infested soil amended } \\
\text { with }\end{array}$} & \multirow[t]{3}{*}{$\begin{array}{c}\text { Rate g } \\
(\%)\end{array}$} & \multicolumn{4}{|c|}{$\begin{array}{l}\text { Tested enzyme activity in } \\
\text { potato plants }\end{array}$} & \multicolumn{4}{|c|}{$\begin{array}{c}\text { Tested enzyme activity in } \\
\text { tomato plants }\end{array}$} \\
\hline & & \multicolumn{2}{|c|}{ Polyphenol oxidase } & \multicolumn{2}{|c|}{ Peroxidase } & \multicolumn{2}{|c|}{ Polyphenol oxidase } & \multicolumn{2}{|c|}{ Peroxidase } \\
\hline & & $\mathbf{A}$ & Cont. & $\mathbf{A}$ & Cont. & A & Cont. & $\mathbf{A}$ & Cont \\
\hline \multirow{2}{*}{ Animal manure } & 10 & 0.408 & 0.294 & 0.525 & 0.453 & 0.286 & 0.254 & 0.454 & 0.334 \\
\hline & 20 & 0.485 & 0.372 & 0.559 & 0.463 & 0.374 & 0.315 & 0.485 & 0.373 \\
\hline \multirow{2}{*}{ Mixture1 } & 10 & 0.306 & 0.28 & 0.378 & 0.281 & 0.253 & 0.235 & 0.565 & 0.437 \\
\hline & 20 & 0.356 & 0.309 & 0.413 & 0.335 & 0.262 & 0.246 & 0.575 & 0.482 \\
\hline \multirow{2}{*}{ Mixture2 } & 10 & 0.242 & 0.235 & 0.425 & 0.390 & 0.176 & 0.165 & 0.388 & 0.266 \\
\hline & 20 & 0.263 & 0.252 & 0.472 & 0.425 & 0.195 & 0.187 & 0.399 & 0.286 \\
\hline \multirow{2}{*}{ Vegetarian (sugar cane) } & 10 & 0.209 & 0.186 & 0.326 & 0.241 & 0.152 & 0.141 & 0.290 & 0.223 \\
\hline & 20 & 0.215 & 0.205 & 0.344 & 0.246 & 0.156 & 0.147 & 0.340 & 0.230 \\
\hline \multirow{2}{*}{ Vegetarian (etr) } & 10 & 0.185 & 0.156 & 0.291 & 0.215 & 0.161 & 0.151 & 0.231 & 0.177 \\
\hline & 20 & 0.195 & 0.167 & 0.309 & 0.231 & 0.167 & 0.156 & 0.277 & 0.196 \\
\hline \multirow{2}{*}{ Poultry } & 10 & 0.153 & 0.13 & 0.273 & 0.181 & 0.143 & 0.137 & 0.162 & 0.152 \\
\hline & 20 & 0.175 & 0.136 & 0.280 & 0.197 & 0.149 & 0.143 & 0.188 & 0.173 \\
\hline \multirow{2}{*}{ Dove } & 10 & 0.132 & 0.123 & 0.227 & 0.148 & 0.134 & 0.123 & 0.143 & 0.132 \\
\hline & 20 & 0.140 & 0.127 & 0.251 & 0.162 & 0.137 & 0.128 & 0.153 & 0.140 \\
\hline Infested soil -Untreated control & & 0.391 & 0.332 & 0.442 & 0.377 & 0.130 & 0.285 & 0.114 & 0.339 \\
\hline
\end{tabular}

Mixture1 $=($ Animal manure + Vegetarian $)$ Mixture2 $=($ Animal manure + Poultry $)$

$\mathrm{A}=$ Infected plants with Ralstonia solanacearum Cont.= Healthy plants

\section{REFERENCES}

Abbasi, P.A., J. Al-Dahmani, F. Sahin, H.A.J. Hoitink and S.A. Miller (2002). Effect of compost amendments on disease severity and yield of tomato in conventional and organic production systems. Plant Dis., 86: 156-161.

Abd El-Mouty, M.M.A., H. Ali and F.A. Rizk (2001). Potato yield as affected by the interaction between bio and organic fertilizers. Egypt. J. Appl. Sci., 16 (6): $267-$ 286.

Abd-Elrahim, R., M.M. Atia, M.R.A. Tohamy and N.M. El-Sarkassy (2015). Isolation and identification Ralstonia solanacearum the causal organism of potato brown rot from different sources and regions of Egypt. Zagazig J. Agric. Res., 42 (2): 269-281.

Amemiya, Y. (2007). Control of soil borne plant disease by compost amendments, Soil Microorganism, Japan., 61:123-128.

Ancuța, D., Ș. Renata and R. Șumălan (2013). Influence of different types of composts on growth and chlorophyll content from tomato seedlings. J. Horticul., Fores. and Biotechnol., 17 (4): $43-48$.

Awad, E.M. (2002). Effect of compost and some bio-fertilizers on growth, yield and quality of potato crops (Solanum tubersum, L.). J. Agric. Sci, Mansoura Univ., 27 (8): 5525-5537.

Babitha, M.P., H.S. Prakash and H.S. Shetty (2004). Purification and properties of 
lipoxygenase induced in downy mildew resistant pearl millet seedlings due to infection with Sclerospora graminicola. Plant Sci., 166 : 31-39.

Bailey, K.L. and G. Lazarovits (2003). Suppressing soil borne diseases with residue management and organic amendments. Soil Tillage, 72: 169-180.

Banda, A., T. Mubyana-John and J.E. Taylor (2011). The influence of range fire on soil fungi, microbial activity and soil properties along the Boro Route of the Okavango Delta. The African J. of Pl.Sci. and Biotech., 5(1): 56-62.

Bulluck, L.R., M. Brosius, G.K. Evanylo and J.B. Ristaino (2002). Organic and synthetic fertility amendments influence soil microbial, physical and chemical properties on organic and conventional farms. Appl. Soil Ecol., 19: 147-160.

Caruso, C., G. Chilosi, L. Leonard, L. Bertin, P. Magro, V. Buonocore and C. Caporal (2001). A basic peroxidase from wheat kernel with antifungal activity. Phytochem., 58: 743-750.

Colburn-Clifford, J. and C. Allen (2010). A type cytochrome $\mathrm{C}$ oxidase contributes to Ralstonia solanacearum R3bv2 growth in microaerobic environments and to bacterial wilt disease development in tomato. Mol. Pl.Microbe Interact., 23 (8): 1042-1052.

Datnoff, L.E., KW. Seebold and V.F.J. Correa (2001). The use of silicon for integrated disease management: reducing fungicide applications and enhancing host plant resistance. In: "Silicon in Agriculture" (L.E. Datnoff, L.E.; Snyder, G.H. and Korndorfer, G.H. Ed.). The Netherlands, Elsevier, 171183.

Denny, T.P. (2006). Plant Pathogenic Ralstonia species. Pages 573-644 In: Plant-Associated Bacteria. SS, Gnanamanickam, ed. Springer Publishing, Dordrecht, The Netherlands.

El-Desuki, M., M.M., Hafez, A.R. Mahmoud, and F.S. Abd El-Al (2010). Effect of organic and bio- fertilizers on the plant growth, green pod yield, quality of pea. Inter. J. Acad. Res., 2 (1): 87-92.
El-Etr, W.T., L.K.M. Ali and E.L. El-Khatib (2004). Comparative effects of bio-compost and compost on growth yield and nutrients content of pea and wheat plants grown on sandy soils. Egypt. J. Agric. Res., 82 (2): $73-$ 94 (special issue).

Fadeel, A.A. (1962). Location and properties of chloroplasts and pigment determination in roots. Physiol. Plant., 15: 130 - 147.

Gado, E.A.M. (2013). Induction of resistance potato plants against bacterial diseases under Egyptian conditions. J. Appl. Sci. Res., 9 (1): 170- 177.

Gina, M.E.E., T. Usami and Y. Amemiya (2008). Effect of compost amendment on soil microbial community and pathogen causing fusarium wilt disease of spinach, Hort. Res., 62: 21-29.

Girish, N. and S. Umesha (2005). Effect of plant growth promoting rhizobacteria on bacterial canker of tomato. Arch. Phytopathol. Plant Prot., 38:235-243.

Gomez, K.A. and A.A. Gomez (1984). Statistical Procedures for Agricultural Research. $2^{\text {nd }}$ Ed., Wiley and Sons, New York. USA.

Gorissen, A., L.S. van Overbeek and J.D. Van Elsas (2004). Pig slurry reduces the survival of Ralstonia solanacearum biovar 2 in soil. Cana. J. Microbiol., 50: 587-593.

Hammerschmidt, R., E.M. Nuckles and J. Kuc (1982). Association of enhanced peroxidase activity with induced systemic resistance of cucumber to Colletotrichum lagenarium. Physiol. Plant Pathol., 20: 73-82.

Hayward, A.C. (1991). Biology and epidemiology of bacterial wilt caused by Pseudomonas solanacearum, Annu. Rev. Phytopathol., 29: 67-87.

Hayward, A.C., J.C. Elphistone, D. Caffier, J. Jense, E. Stefani, E.R. French and A.J. Wright (1998). Bacterial Wilpt Disease, Molecular and Ecological Aspects, Eds. By Prior, P., Allen, C. Elphinstonne, J. SpringerVerlag, Berlin.

Heinze, S., M. Oltmanns, R.G. Joergensen and J. Raupp (2011). Changes in microbial biomass 
incidence after 10 years of farmyard manure and vegetal fertilizer application to a sandy soil under organic management. Plant Soil, 343: 221-234.

Hernández, G.L. and E.R. Bustamante (2001). Biological control of bacterial wilt in tomato with organic amendments. Manejo Integrado de Plagas, (62):18-28. (c.f. Rev. Plant Pathol., 81 (10): 1427.

Hoitink, H.A.J. and M.J. Boehm (1999). Biocontrol within the context of soil microbial communities: a substrate dependent phenomenon. Ann. Rev. Phytopathol., 37: 427-446.

Islam, T.M.D. and K. Toyota (2004). Suppression of bacterial wilt of tomato by Ralstonia solanacearum by incorporation of composts in soil and possible mechanism. Microb. Environ., 19: 53-60.

Jacobs, M.J. and M.J. Gerstein (1960). Handbook of Microbiology. D. Van Nostrand Company, Inc., London.

Jahromi, M.G., A. Aboutalebi and M.H. Farahi (2012). Influence of different levels of garden compost (garden wastes and cow manure) on growth and stand establishment of tomato and cucumber in greenhouse condition. African J. Biotechnol., 11 (37): 9036-9039.

Janvier, C., F. Villeneuve, C. Alabouvette, V. Edel-Hermann, T. Mateille and C. Steinberg (2007). Soil health through soil disease suppression: Which strategy from descriptors to indicators. Soil Biol. and Biochem., 39:123.

JianHua, Z., Z. GuangMing, Z. Jun and Y. JinHua (2012). Effects of three composts on growth and bacterial wilt of tomato. Plant Nutr. and Fert. Sci., 18(5):1192-1200.

Kelman, A. (1954). The relationship of pathogenicity in Pseudomonas solanacearum to colony appreance on a tetrazolium medium. Phytopathol., 44:693-695.

Kochba, J., S. Lavee and P. Spie-Roy (1977). Difference in peroxidase activity and isozymes in embryogenic and nonembryogenic orange ovular callus lines. Plant and Cell Physiol., 18 (46):3-7.
Kohl, I. and N.J. Fokkema (1998). Strategies of biological control of necrotrophic fungal foliar pathogens. In Plant-Microbe interactions and biological control (G. Boland and L.D. Kuykendall, Eds.). Marcel Dekker, Inc., New York W., 49-88.

Lelliott, R.A. and D.E. Stead (1987). Methods for diagnosis of bacterial diseases of plants. Methods in Plant Pathology, Vol.2 Ed. T.F. Preece. Blackwell Sci. Publication, 216.

Lisker, N., L. Cohen, E. Chaluz and Y. Fuchs (1983). Fungi infection suppress ethyleneinduced phenylalanine ammonia-lyase activity in grap fruit. Physiol. Plant Pathol., 22 (33): 331-338.

Litterick, A.M., L. Harrier, P. Wallace, C.A. Watson and M. Wood (2004). The role of uncomposted materials, composts, manures and compost extracts in reducing pest and disease incidence and severity in sustainable temperate agricultural and horticultural crop production- A Review. Crit. Rev. in Plant Sci., 23:453-479.

Millner, P.D., C.E. Ringer and J.L. Maas (2004). Suppression of strawberry root disease with animal manure composts. Compost Sci. Utiliz., 12: 298-307.

Nawar, H.F. and J.D. Kuti (2003). Wyerone acid phytoalexin synthesis and peroxidase activity as markers for resistance of broad beans to chocolate spot disease. J. Phytopathol., 151: 564-570.

Nishiyama, M., Y. Shiomi, S. Suzuki and T. Marumoto (1999). Suppression growth of Ralstonia solanacearum, tomato bacterial wilt agent, on/in tomato seedlings cultivated in a suppressive soil. Soil Sci. and Plant Nutr., 45: 79-87.

Peeters, N., A. Guidot, F. Vailleau and M. Valls (2013). Ralstonia solanacearum, a widespread bacterial plant pathogen in the post-genomic. Mol. Plant Pathol., 14 (7): 651-662.

Pena, M. and J.A. Kuc (1992). Peroxidasegenerated hydrogen peroxidase as a source of antifungal activity in vitro and on tobacco leaf disks. Phytopathol., 82: 696-699. 
Ride, J.P. and R.B. Pearce (1979). Lignification and papillae formation at sities of attempted penetration of wheat leaves by nonpathogenic fungi. Physiol. Plant Pathol., 15: 79-92.

Saddler, G.S. (2005). Management of Bacterial Wilt Disease. p. 121-132. In: Bacterial Wilt Disease and Ralstonia solanacearum species Complex (Allen,C. P; Prior, P. and Hayward, A.C. Ed.). The APS Press, St. Paul, MN, USA, 528.

Sakthivigneswari, G. and A. Vijayalakshmi (2016). Effect of different bio-composting techniques on physio-chemical changes in corncob. South Indian J. Biol. Sci., 2 (1) : 6165.

Schönfeld, J.A., L.S. Gelsomino, A. Van Overbeek, K.S. Gorissen and J.D.Van Elsas (2003). Effects of compost addition and stimulated solarization on the fate of Ralstonia solanacearum biovar 2 and indigenous bacteria in soil. FMES Microbiol. of Ecol., 43: 63-74.

Shirling, E.B. and D. Gottlieb (1966). Methods for characterization of Streptomyces species. Int. J. Syst. Bacteriol., 16:313-340.

Shivakumar, P.D., H.M. Geetha and H.S. Shetty (2003). Peroxidase activity and isozymes analysis of pearl millet seedlings and their implication in downy mildew disease resistance. Plant Sci., 164 (1):85-93.

Soe, K.K., Y.Y. Min, M.Z. Aung and T.A.A. Naing (2016). Evaluation of different control measures on bacterial wilt of tomato caused by Ralstonia solanacearum. J. Agric. Res., 4 (1) 113-116.

Tarrad, A.M., H.Y.Y. El-Hyatemy and S. Omar (1993). Wyerone derivatives and activities of peroxidase and polyphenol oxidase in faba bean leaves as induced by chocolate spot disease. Plant Sci. Limerick, 89 (2): 161-165.

Termorshuizen, A.J., E. Van Rijin, D.J. Van de Gaag, Y. Chen, J. Lagerlof, E.J. Paplomatas,
B. Ramert, C. Steinberg and S. Zmora (2006). Disease suppression of 18 composts against 7 pathogens. Soil Biol. and Bioch., 38:2461-2477.

Thipyapong, P., J.M. Stout and E. Attajarusit (2007). Functional analysis of polyphenol oxidases by antisense/sense technology. Rev. Molec., 12: 1569-1595.

Van Wees, S.C.M., S. van der Ent and C.M.J. Pieterse (2008). Plant immune responses triggered by beneficial microbes. Plant Biol., 11: 443-448.

Veeken, A.H.M., W.J. Blok, F. Curci, G.C.M. Coenen, A.J. Termorshuizen and H.V.M. Hamelers (2005). Improving quality of composted biowaste to enhance disease suppressiveness of compost-amended, peatbased potting mixes. Soil Biol. and Bioch., 37: 2131-2140.

Wettestein, D. (1957). Chlorophyll-Lethal undder submink roskopische formivechoel der plastiden. Exp. Cell. Res., 12: 427 - 433.

Winstead, N.N. and A. Kelman (1952). Inoculation techniques for evaluation resistance Pseudomonas solanacearum. Phytopathol., 42: 628-634.

Yadessa, G.B., A.H.C.V. Bruggen and F.L. Ocho (2010). Effects of different soil amendments on bacterial wilt caused by Ralstonia solanacearum and on the yield of tomato. Plant Pathol., 92 (2): 439-450.

Youssef, S.A. and K.A.H. Tartoura (2013). Compost enhances plant resistance against the bacterial wilt pathogen Ralstonia solanacearum via up-regulation of ascorbateglutathione redox cycle. Eur. J. Plant Pathol., 137 (4): 821-834.

Zhang, W., D.Y. Han, W.A. Dick, K.R. Davis and H.A.J. Hoitink (1998). Compost and compost water extract-induced systemic acquired resistance in cucumber and arabidopsis. Phytopathol., 88: 450-455. 


\title{
دور الإضافات العضوية في مقاومه الذبول البكتيري في بعض نباتات العائلة الباذنجانية تحت ظروف العدوي الصناعية الكية فيرن
}

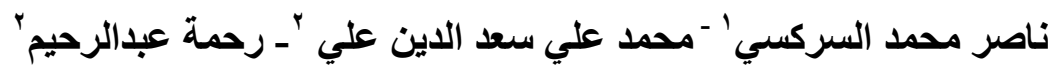

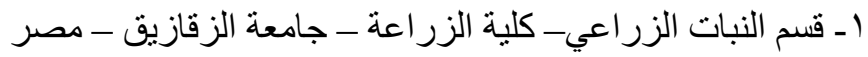

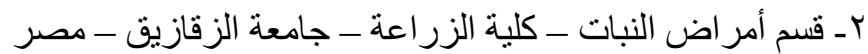

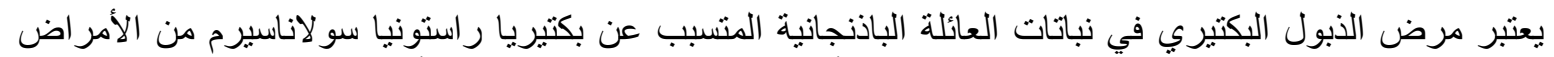

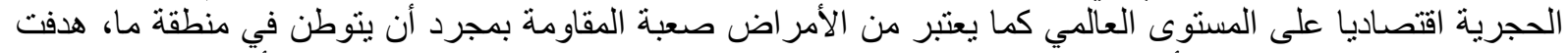

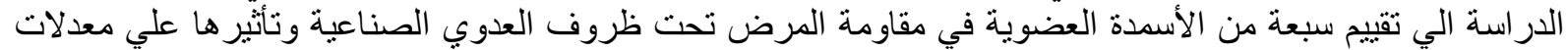

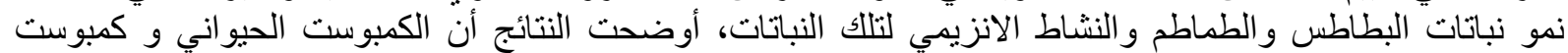

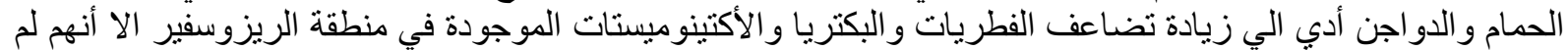

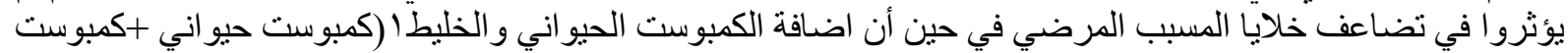

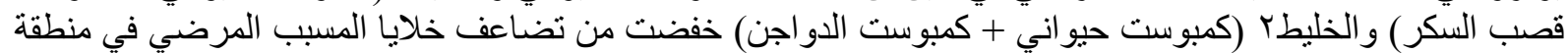

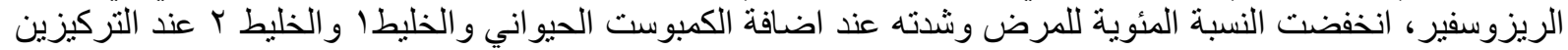

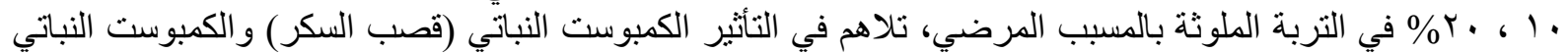

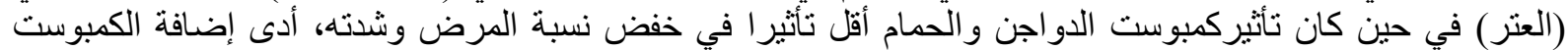

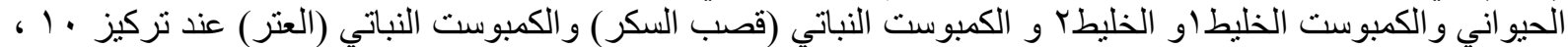

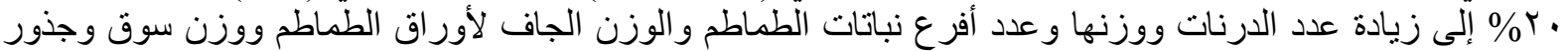

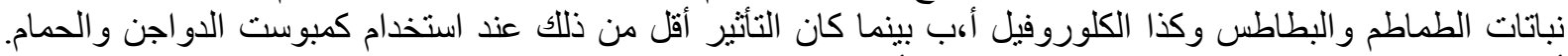
أظهرت النتائج زيادة نشاط إنزيمي البولي فينول أوكسيديز والبيروكسيديز بدرجات مختلفة في النباتات طبقا لاختلاف 